\title{
Evaluation of Adolescents with Restless Legs Syndrome: Relation to School Success
}

\author{
Author(s) @Neslihan Günay1, ๑Sevda İsmailoğulları², ๑Esra Özdemir Demirci³, \\ (-) Fatih Kardaş ${ }^{4}$, Hüseyin Per $^{5}$
}

${ }^{1}$ Kayseri City Research and Training Hospital, Department of Pediatric Nephrology, Kayseri, Turkey

Affiliation

(s)

${ }^{2}$ Erciyes University Medical Faculty, Department of Neurology, Division of Sleep Medicine, Kayseri, Turkey

${ }^{3}$ Erciyes University Medical Faculty, Department of Child Psychiatry, Kayseri, Turkey

${ }^{4}$ Erciyes University Medical Faculty, Department of Pediatrics, Division of Nutrition and Metabolism, Kayseri, Turkey

${ }^{5}$ Erciyes University Medical Faculty, Department of Pediatrics, Division of Pediatric Neurology, Kayseri, Turkey

Article

Information
Article Type: Original Articles

Article Group: Pediatric Neurology
Received: 20.10.2021

Accepted: 07.12.2021

Available Online: 31.12 .2021

\section{Abstract}

Restless Legs Syndrome (RLS), which may be a missed diagnosis in children, is seen at an important frequency. The aim of this study was to investigate the clinical characteristics of patients with RLS and to show the effect of RLS on school success. Forty-three patients with RLS and 43 healthy volunteers were included to the study. Blood samples were taken to measure ferritin. The averages of school exam scores were recorded. The patient group was classified as mild, moderate, severe, and very severe according to the RLS rating scale. The daytime sleepiness was measured by the Epworth Sleepiness Scale (ESS). The"Turgay DSM-IV-Based Child and Adolescent Disruptive Behavioral Disorders Screening and Rating Scale (T-DSM-IV-S)" was completed by parents, and patients' inattention, and hyperactivity-impulsivity scores were compared with the control group. According to the RLS rating scale scores $25.6 \%(n: 11)$ were evaluated as mild, $60.5 \%(n: 26)$ were moderate and $14 \%(n: 6)$ were severe. The mean ferritin level was significantly lower in the patient group. The mean score of inattention and hyperactivity-impulsivity in the patient group to be significantly higher than the control. The mathematics and science course mean grades were significantly lower in the patient group than the controls $(66.7 \pm 17.7$ vs $74.2 \pm 11.7)$. ESS scores were found to be significantly higher in the patient group. In this study, RLS has been found associated with ADHD and iron deficiency, similar to previous studies. There are not many studies on the effects of RLS in children on daily life and this study has objectively shown that RLS reduces patients' school achievement.

Keywords: Adolescents, restless legs syndrome, sleep related movement disorders, Fabry's disease

Correspondence: Neslihan Günay, Erciyes University Medical School, Department of Pediatric Nephrology Talas, Kayseri, Turkey

E-mail: neslihankosr@hotmail.com 


\section{Introduction}

Restless Legs Syndrome (RLS) is a sensory-motor disorder that causes a need of movement in the limbs. It is classified as sleep related movement disorder. ${ }^{1,2}$ Typically, symptomsget worse during rest especially in the evening, and are relieved with movement. ${ }^{2,3}$ RLS can be seen as primary, or secondary to chronic renal failure, iron deficiency anemia, and pregnancy. Primary RLS is seen at younger ages and often has a familial history. ${ }^{3}$

Genetic factors, dopaminergic dysfunction of the central nervous system (CNS), and iron deficiency in brain tissues are shown among the causes of RLS. ${ }^{2,4}$ Iron deficiency is the most common cause of RLS. ${ }^{3}$ Iron acts as a cofactor for tyrosine hydroxylase, a ratelimiting enzyme in dopamine synthesis. Iron dysregulation may cause dopamine abnormalities in RLS. ${ }^{1,4}$ It is known that iron treatment improves symptoms when serum ferritin is below $50 \mathrm{ng} /$ $\mathrm{mL}{ }^{5}$

\section{Muscle disorders, muscle} cramps, positional disturbances, vascular diseases, peripheral nerve diseases, joint disorders, attention deficit hyperactivity disorder (ADHD), periodic leg movement disorder (PLMD), Fabry's disease and growth pains are included in the differential diagnosis. ${ }^{1,6,7}$ Coexistence with iron deficiency, ADHD, or chronic renal failure are more frequent. ${ }^{8}$ Iron deficiency and CNS dopaminergic dysfunction plays a role in the pathophysiology of ADHD such as RLS. ${ }^{8}$ Fabry's disease is a X-linked recessive disorder characterized by a deficiency in the activity of a-Galactosidase A. Symptoms are defined as burning, tingling and disturbing pain in hands and feet. It usually starts in the first decade and decreases with age. Fabry disease is very rare, but symptoms can be confused with RLS and patients may be misdiagnosed. ${ }^{7}$ Restless Legs Syndrome is rated as mild, moderate, severe, and very severe, according to the RLS rating scale developed by the International Restless Legs Syndrome Working Group (IRLSSG). This scale, which is used to determine the severity of the disease and the need for treatment, assesses how much the symptoms affect quality of life and the frequency of symptoms. ${ }^{9}$

Restless Legs Syndrome may get worse if not treated. It affects patients' sleep quality, daily activities, emotional states, and energy negatively. Patients have difficulty initiatingand maintaining sleep.This causes impaired concentration, depression, anxiety, sleepiness, and poor work performance leading to sleep disorders. All of these have been shown to reduce the quality of life of patients. ${ }^{10,11}$

RLS is seen with a high frequency, but it is often misdiagnosed.The number of studies examining the effects of RLS on school success is very few. The aim of this study was to investigate the clinical characteristics of 43 patients with diagnosed RLS and to show the effect of RLS on school success.

\section{Material and Method}

This study was performed at Erciyes University's Faculty of Medicine after Erciyes University Clinical Research Ethics Committee approval. All procedures were carried out in accordance with the ethical rules and the principles of the Declaration of Helsinki.

There was an earlier study conducted in Kayseri provincial central to determine the prevalence of RLS in 13-16-years old adolescents. Fourty three voluntary patients who had been diagnosed with RLS by survey and telephone interview, from the previous study were included in the present study. ${ }^{13}$ Fourty three healthy volunteers of similar age and sex were identified as the control group.

Detailed physical examinations of the patients and control groups were performed. Blood samples were taken from both groups to measure complete blood count, liver and kidney function tests, ferritin and vitamin B12, and cholesterol levels. Blood sample was also taken from the patient group to measure the level of $\alpha$-galactosidase for use in the Fabry disease marker. The average history, literature, mathematics and science exam scores from the end of the last year were recorded.

The RLS Rating Scale, consisting of ten questions, was applied and patients were classified as mild, moderate, and severe according to this scale. There were no patients classified as very severe. These groups were compared according to ferritin levels and lesson exam scores.

The daytime sleepiness of the patient and control groups were measured by the Epworth Sleepiness Scale (ESS). The Turgay DSM-IV-Based Child and Adolescent Disruptive Behavioural Disorders Screening and Rating Scale (T-DSM-IV-S) is scale, developed by Turgay, which is mainly used for screening disruptive behavior disorders including ADHD, oppositional defiant disorder, and general behavioral disorders; and its reliability and validity studies for the Turkish version were done by Ercan et al. ${ }^{14,15}$ The scale consists of 41 questions, 9 for hyperactivity, 9 for attention deficit, 8 for oppositional defiance, and 15 for general behavioural disorders. The severity of each item is measured by a four-point Likerttype scale. In our study, the T-DSM-IV-S was fulfilled by parents of both the patient and control groups. Parents were informed how to complete and use the scoring system of the T-DSM-IV-S.

The data was evaluated using the SPSS 15.0 package program. In statistical analysis, the Pearson Chi-square test, Fisher's exact test, unpaired t test, one way ANOVA test (post hock Scheffe test), and logistic regression analysis were used. Values of $p<0.05$ were considered significant. 


\section{Results}

Gender and age distributions of patients and control groups were equal; $60.5 \%$ of the groups $(n=26)$ were girls and $39.5 \%(n=17)$ were boys. The mean age was $14.5 \pm$ 1.0 years (min: 13 max: 16). In the patient group,2 people had iron deficiency, 2 people had ADHD, and 1 person had chronic hepatitis B. Totally, five patients were receiving treatment. None of the participants in the control group had additional pathology. In both groups, the physical examinations of the participants were normal and there were no orthopaedical problems or any infection findings.

According to the RLS rating scale scores $25.6 \%$ (n: 11) were mild, $60.5 \%$ (n: 26) were moderate and $14 \%$ (n: 6) were grouped as severe.

Mean ferritin level found $29.2 \pm 16.0 \mathrm{ng} / \mathrm{mL}$ in the patient group and $44.8 \pm 28.0 \mathrm{ng} / \mathrm{mL}$ in the control group. The difference was statistically significant $(p=0.002)$. Ferritin values were significantly higher in the milder group but no difference was found between the moderate and severe groups (Table 1).

There was no significant difference between the patient and control groups from the standpoints of vitamin B12, triglyceride and cholesterol levels (Table 2). Alpha Galactosidase enzyme level was measured for Fabry disease diagnosis in patient group and enzyme deficiency was not detected.

\section{Table 1}

Ferritin Values According to RLS Severity

\begin{tabular}{lcc}
\hline RLS Severity & $\mathbf{n}$ & Ferritin $(\mathbf{n g} / \mathbf{m L})($ Mean $\pm S D)$ \\
\hline Mild & 11 & $41.0 \pm 11.0^{\mathrm{a}}$ \\
Moderate & 26 & $25.8 \pm 16.8^{\mathrm{b}}$ \\
Severe & 6 & $21.9 \pm 7.5^{\mathrm{b}}$ \\
Total & 43 & $29.2 \pm 16.0$ \\
\hline
\end{tabular}

$F=5.01, p=0.011$, a,b: The difference between groups with different letters is significant.

Table 2

Comparison of B12 vitamin, Triglyceride and Cholesterol Values in Patient and Control Groups

\begin{tabular}{lccc}
\hline Values & $\begin{array}{c}\text { Patient }(\mathbf{n = 4 3}) \\
(\text { Mean } \pm \text { SD) }\end{array}$ & $\begin{array}{c}\text { Control }(\mathbf{n = 4 3 )} \\
(\text { Mean } \pm \text { SD) }\end{array}$ & p \\
\hline B12 $(\mathrm{pg} / \mathrm{mL})$ & $291.1 \pm 119$ & $288 \pm 88.2$ & 0.786 \\
Triglyceride $(\mathrm{mg} / \mathrm{dL})$ & $114.3 \pm 57.8$ & $97.9 \pm 44.2$ & 0.146 \\
Cholesterol $(\mathrm{mg} / \mathrm{dL})$ & $138.2 \pm 25.2$ & $137.4 \pm 24.4$ & 0.881 \\
\hline
\end{tabular}

The mean grades of mathematics and science courses were found significantly lower in the patient group than the controls. $(66.7 \pm 17.7$ vs $74.2 \pm 11.7)(p=0.022)$. However, the mean grades of history and literature in the study groups were not significantly different $(75.2 \pm 13.5$ vs $77.2 \pm 9.0)(p>0.05)$. In patients classified as severe, the mean grade point was lower than in the other groups; but there was no statistically significant difference between the groups (Table 3)

The "DSM-4 based Scanning and Assessment Scale for Behavioral Disorders in Children and Adolescents" was filled out by parents. The mean score of inattention and of hyperactivity-impulsivity in the patient group $(9.30 \pm 6.63 / 8.91 \pm 6.14)$ was significantly higher than the control group (5.84 $\pm 3.81 / 4.91 \pm 3.09)$. Additionally, the mean scores of mild, moderate, and severe groups were compared and no significant difference was found between the groups (Table 4).

Daytime sleepiness was accepted when the ESS score was 10 or more. Mean ESS scores and daytime sleepiness in the patient and control groups were compared. Both ESS scores and percentage of daytime sleepiness were found significantly higher in the patient group (Table 5)

\section{Discussion}

The number of studies on the effect of RLS on daily life in children is increasing. Studies have been carried out to examine the daily life effects of RLS, which is known to distrupt sleep quality and to cause the patients to work poorly; but there have been few studies on school achievement. In a study performed by Yılmaz et al, children were asked to describe their school success as good-medium-poor and school performance was found to be poorer in RLS cases. ${ }^{16}$ Similarly, in this study, the lesson's exam scores of the patients and control groups

Table 5

ESS Scores and Daytime Sleepiness in Patient and Control

\begin{tabular}{lcccc}
\hline \multirow{2}{*}{ Groups } & $\mathbf{n}$ & ESS score & \multicolumn{2}{c}{ Daytime Sleepiness } \\
\cline { 3 - 5 } & 43 & Mean \pm SD & Number & $\%$ \\
\hline Patient & 43 & $6.5 \pm 3.6$ & 29 & 67.4 \\
Control & 43.4 & 9 & 20.9 \\
\hline $\mathrm{t}=5,641, \mathrm{p}<0.001, \mathrm{X}^{2}=18.860, \mathrm{p}<0.001$ & & &
\end{tabular}

Table 3

History and Literature) and Mathematics and Science Lessons Scores According to the severity of RLS

\begin{tabular}{|c|c|c|c|c|c|}
\hline \multirow[b]{2}{*}{ Lesson } & \multicolumn{4}{|c|}{ Severity of RLS } & \multirow[b]{2}{*}{$\mathbf{p}$} \\
\hline & $\begin{array}{l}\text { Mild }(n=11) \\
(\text { Mean } \pm S D)\end{array}$ & $\begin{array}{l}\text { Moderate }(n=26) \\
(\text { Mean } \pm S D)\end{array}$ & $\begin{array}{c}\text { Severe } \quad(n=6) \\
(\text { Mean } \pm S D)\end{array}$ & $\begin{array}{c}\text { Total } \quad(n=43) \\
(\text { Mean } \pm S D)\end{array}$ & \\
\hline History and Literature & $71.5 \pm 14.5$ & $77.0 \pm 13.0$ & $74.7 \pm 15.3$ & $75.2 \pm 13.6$ & 0.536 \\
\hline Mathematics and Science & $64.9 \pm 18.4$ & $70.0 \pm 16.2$ & $55.6 \pm 20.5$ & $66.7 \pm 17.6$ & 0.187 \\
\hline
\end{tabular}

\begin{tabular}{|c|c|c|c|c|c|}
\hline \multirow{2}{*}{ Scores } & \multicolumn{3}{|c|}{ Severity of RLS } & \multirow{2}{*}{$\mathbf{F}$} & \multirow{2}{*}{$p$} \\
\hline & Mild (n=11) & Moderate $(n=26)$ & Severe $(n=6)$ & & \\
\hline Inattention Score (Mean \pm SD) & $8.91 \pm 6.38$ & $8.69 \pm 6.42$ & $12.67 \pm 7.37$ & 0.927 & 0.404 \\
\hline Hyperactivity-Impulsivity Score (Mean \pm SD) & $7.00 \pm 7.04$ & $9.19 \pm 5.41$ & $11.17 \pm 7.49$ & 0.963 & 0.390 \\
\hline
\end{tabular}


were compared. The Mean grade of mathematics and science courses were found significantly lower in the patient group. In patients classified as severe, the mean grade point was lower than in the other groups; but there was no statistically significant difference between the groups. This situation has been associated with RLS causing problems in focusing on the lesson. This may be preceded by the fact that RLS causes leg pain, sleep and movement problems. Further studies are needed to quantitatively measure focus and attention skills in RLS patients.

Iron deficiency is known to be involved in the causes of Restless Legs Syndrome and improvements in the symptoms of patients with iron treatments were achieved, even if serum iron levels and haemoglobin levels were normal. In some adult studies, ferritin margins that are considered normal, such as $50 \mathrm{ng} /$ $\mathrm{mL}$ for $75 \mathrm{ng} / \mathrm{mL}$, have been shown as limit values for starting treatment in RLS. ${ }^{17-19}$ In our study, Ferritin values of the groups were compared and were found lower in the patient group than in the control group. According to the degree of disease, Ferritin values were found highest in the mild disease group than in the other two groups. There was no difference between the moderate and severe groups, but this could be due to the small number of cases in the group. Considering that sensory disturbances that may develop due to lack of vitamin B12 might be mixed with the disturbing sensations in RLS, vitamin B12 levels were compared in the patient and control groups; and there was no significant difference between the groups.

In a study conducted by Dominguez et al. in Fabry patients; it has been shown that RLS symptoms may be related to neuropathic pain, and symptoms are reduced by enzyme treatment. ${ }^{7}$ In this study, the enzyme activity of alpha galactosidase was checked for Fabry's disease in the patient group, and enzyme deficiency was not detected.

ADHD is a disorder associated with RLS, and in both, the pathophysiology is characterized by iron deficiency. According to previous studies, approximately $25 \%$ of RLS patients have ADHD, whereas $12 \%$ to $35 \%$ of ADHD cases have RLS. ${ }^{19}$ Picchietti et al. found that $23.9 \%$ of children between $8-11$ years of age and $26.8 \%$ of children between 12-17 years of age, have RLS accompanied with ADHD. ${ }^{20}$ In our study, carelessness and impulsivity-hyperactivity scores in the patient group were significantly higher than the control group.

Restless Legs Syndrome worsens the quality of life of patients when their diagnosis is delayed or untreated. RLS has been shown to cause depression, anxiety, daytime sleepiness, and poor work performance, with sleep disturbance the leading problem. ${ }^{20-22}$ Picchietti et al. found sleeping disorders in $69.4 \%$ of patients with RLS. ${ }^{20}$ In our study, the mean EES score was found to be $10.8 \pm 3.4$ in the RLS group, and $6.5 \pm 3.6$ in the control group. $67.4 \%$ of the RLS patients had daytime sleepiness similar to the above mentioned study (ESS score $>10)$.

\section{Conclusion}

In this study, RLS has been found to be associated with ADHD and iron deficiency, like previous studies. There are few studies on the daily life effects of RLS, which is difficult to diagnose, in children and this study has shown objectively that RLS reduces patients' school achievement.

Author Contributions: All of the authors declare that they have all participated in the design, execution, and analysis of the paper, and that they have approved the final version.

Conflict of Interest: There are no conflicts of interest in connection with this paper, and the material described is not under publication or consideration for publication elsewhere.

Ethics Committee Approval: For this study, approval number "2014/33" of the local ethics committee of Erciyes University Clinical Researches was obtained.

Financial Disclosure: This study was supported by the Erciyes University Scientific Research Projects Unit.

Informed Consent: Informed consent was obtained from the parents of the patients.

\section{References}

1. American Academy of Sleep Medicine. International classification of sleep disorders, 2nd ed. Diagnostic and coding manual. Westchester, Illinois: American Academy of Sleep Medicine, 2005.

2. Picchietti DL, Picchietti MA. Restless Legs Syndrome. In: Kothare SV, Kotagal S, eds. Sleep in Childhood Neurological Disorders. New York. Demos Medical,2011:57-70.

3. Durmer JS. Restless Legs Syndrome, Periodic Leg Movements and Periodic Limb Movement Disorder. In: Sheldon SH, Ferber $\mathrm{R}$, Kryger MH, Gozal D, eds. Principles and Practice of Pediatric Sleep Medicine. 2nd ed. Elseiver, 2014:337-350.

4. Nagandla K, De S. Restless legs syndrome: pathophysiology and modern management. Postgrad Med J. 2013;89:402-410. [CrossRef]

5. Tilma J, Tilma K, Norregaard O, Ostergaard JR. Early childhoodonset restless legs syndrome: symptoms and effect of oral iron treatment. Acta Paediatr. 2013;102:e221-e226. [CrossRef]

6. Marin LF, Felicio AC, Santos WA, Prado LB, Prado GF. Clinical correlates of the restless legs syndrome. Arq Neuropsiquiatr. 2012;70:529-531. [CrossRef]

7. Domínguez RO, Michref A, Tanus E, Amartino H. Sindrome de piernas inquietas en la enfermedad de Fabry: asociación con dolor neuropatico [Restless legs syndrome in Fabry disease: clinical feature associated to neuropathic pain is overlooked]. Rev Neurol. 2007;45:474-478. [CrossRef]

8. Becker PM, Novak M. Diagnosis, comorbidities, and management of restless legs syndrome. Curr Med Res Opin. 2014;30:14411460. [CrossRef]

9. Walters AS, LeBrocq C, Dhar A, et al. Validation of the International Restless Legs Syndrome Study Group rating scale for restless legs syndrome. Sleep Med. 2003;4:121-132. [CrossRef]

10. Silva GE, Goodwin JL, Vana KD, Vasquez MM, Wilcox PG, Quan SF. Restless legs syndrome, sleep, and quality of life among adolescents and young adults. J Clin Sleep Med. 2014;10:779786. [CrossRef]

11. Castillo PR, Mera RM, Fredrickson PA, Zambrano M, Del Brutto VJ, Del Brutto $\mathrm{OH}$. Psychological distress in patients with restless legs syndrome (Willis-Ekbom disease): a population-based doorto-door survey in rural Ecuador. BMC Res Notes. 2014;7:911. [CrossRef] 
12. Altunayoglu Cakmak V, Gazioglu S, Can Usta N, et al. Evaluation of temperament and character features as risk factors for depressive symptoms in patients with restless legs syndrome. $J$ Clin Neurol. 2014;10:320-327. [CrossRef]

13. Per H, Gunay N, Ismailogullari S, Oztop DB, Gunay O. Determination of restless legs syndrome prevalence in children aged 13-16years in the provincial center of Kayseri. Brain Dev. 2017;39:154-160. [CrossRef]

14. Turgay A. Çocuk ve ergenlerde davranım bozuklukları için DSMIV'e dayalı tarama ve değerlendirme ölçeği. Integrative Therapy Institute, Toronto: Kanada, 1995.

15. Ercan E, Amado S, Somer O, Çıkoğlu S. Dikkat eksikliği hiperaktivite bozukluğu ve yıkıcı davranım bozuklukları için bir test bataryası geliştirme çalışması. Çocuk ve Gençlik Ruh Sağığı Dergisi 2001; 8: 132-144.

16. Yilmaz K, Kilincaslan A, Aydin N, Kor D. Prevalence and correlates of restless legs syndrome in adolescents. Dev Med Child Neurol. 2011;53:40-47. [CrossRef]
17. Dosman C, Witmans M, Zwaigenbaum L. Iron's role in paediatric restless legs syndrome - a review. Paediatr Child Health. 2012;17:193-197. [CrossRef]

18. Wijemanne S, Jankovic J. Restless legs syndrome: clinical presentation diagnosis and treatment. Sleep Med. 2015;16:678690. [CrossRef]

19. Picchietti MA, Picchietti DL. Advances in pediatric restless legs syndrome: Iron, genetics, diagnosis and treatment. Sleep Med. 2010;11:643-651. [CrossRef]

20. Picchietti D, Allen RP, Walters AS, Davidson JE, Myers A, FeriniStrambi L. Restless legs syndrome: prevalence and impact in children and adolescents--the Peds REST study. Pediatrics. 2007;120:253-266. [CrossRef]

21. Nagandla K, De S. Restless legs syndrome: pathophysiology and modern management. Postgrad Med J. 2013;89:402-410. [CrossRef] 